DOI: $10.2478 / \mathrm{v} 10025-011-0008-2$

\title{
An assessment of reclamation conditions in the irrigated lands of the Azerbaijan Republic
}

\author{
Garib Shamil MAMMADOV ${ }^{1}$, Agamir Jalal HASHIMOV ${ }^{2}$ \\ ${ }^{1)}$ National Academy of Science of Azerbaijan Republic \\ ${ }^{2)}$ Azerbaijanian Scientific Research Scientific Production Association of Hydraulic Engineering and \\ Amelioration
}

\begin{abstract}
Current reclamation condition of lands in the Azerbaijan Republic and differential assessment of saline soils depending on the soil characteristics (chemistry, soil texture etc.) are described in this paper.
\end{abstract}

Key words: drainage, irrigation, salinity

In the Azerbaijan Republic crops covered an area of 1311.3 thousand ha from the total irrigated area of 1432.7 thousand ha in the year 2008. Cereals covered 499.4 thousand ha, which were irrigated 2.34 times a year on average. The area under cotton crops was irrigated 2.34 times a year and occupied an area of 59.2 thousand ha, tobacco -1.6 thousand ha irrigated 3.68 times, fodder crops -448.8 thousand ha with irrigation -3.28 times, vegetables and watermelons -74.8 thousand ha with irrigation -4.29 times, perennial plants -78.0 thousand ha with irrigation -2.53 times, farmlands -149.5 thousand ha with irrigation -3.87 times [Funds...].

Main factors hampering agricultural development are: shortage of the irrigation water, poor conditions of the irrigation and drainage systems, soil salinity and obstacles arising from the transition to market economy.

According to the Hydrogeology - Ameliorative Service in 2008 only 54.22\% of the irrigated lands were saline-free but other lands showed variable salinity [Cadastre..., 2008]. 31.09\% irrigated lands were weakly saline, $31.09 \%$ moderately saline, and $4.74 \%$ - heavily saline.

To reclaim saline lands, it is important to assess their drainage conditions, which include the following indicators: salinity and alkalinity, chemical composition of dissolved substances, mineralization of ground waters and a set of other factors. Investigations carried out by L.P. Rozova, I.N. Anipova-Karatayeva, N.I. Ba- 
zilevich, V.V. Eqorova, V.A. Kovda, V.P. Volobuyev and others showed that the type of soil salinity showed certain patterns of correlation with chlorides and sulphates. Based on such correlation, important information can be obtained on the drainage-irrigation soil conditions [The problems..., 1960; The works...1974; VoLOBUYEV, 1976].

Centuries-old experience of land reclamation in Azerbaijan enables to adequately assess soil conditions, to define reclamation measures in agro-technical methods and can serve the reliable protection from salinity.

For the Azerbaijan Republic, which is characterized by a wide variety of soilclimatic condition, rating scales of soil salinity have been worked out. Most appropriate is the classification elaborated by V.P. Volobuyev. Depending on salinity he proposed to use the following scale of the average saline content in a $0-100 \mathrm{~cm}$ soil layer (Tab. 1).

Table 1. Classification of the soil by the type and degree of salinity in Azerbaijan [VoLOBUYEV, 1976]

\begin{tabular}{l|c|c|c}
\hline \multirow{2}{*}{$\begin{array}{c}\text { The degree } \\
\text { of salinity }\end{array}$} & \multicolumn{3}{|c}{ Average saline content in the soil layer, \% } \\
\cline { 2 - 4 } & $\begin{array}{c}\text { for the soil of central } \\
\text { alluvial plain with sulphate } \\
\text { chloride and chloride }- \\
\text { sulphate salinity }\end{array}$ & $\begin{array}{c}\text { for the soil with high } \\
\text { content } \\
\text { of gypsum } \\
\text { (Shirvan low-land) }\end{array}$ & $\begin{array}{c}\text { for the soil with } \\
\text { sodium and mixed } \\
\text { salinity } \\
\text { (Mil-Kharabakh lowland) }\end{array}$ \\
\hline Saline-free & $<0.25$ & $<0.80$ & $<0.10$ \\
Weakly saline & $0.25-0.50$ & $0.80-1.20$ & $0.10-0.30$ \\
Moderately saline & $0.50-1.00$ & $1.20-1.50$ & $0.30-0.50$ \\
Heavily saline & $1.00-2.00$ & $1.50-2.00$ & $0.50-0.70$ \\
Very heavily saline & $>2.00$ & $>2.00$ & $>0.70$ \\
\hline
\end{tabular}

Recently, however, in the republic land reclamation practice, soil salinity classification elaborated by V.P. Volobuyev for soils of central alluvial lowland with sulphate-chloride and chloride-sulphate type of salinity has been applied everywhere (Tab. 1). These soils have also a high hydraulic conductivity. Wide application of a specific classification leads to wrong assessment of soil conditions and consequently to inadequate land reclamation measures adopted for these soils. Let's see some particulars. The above mentioned scale is also used for heavy soils with low capability of permeability in the Shirvan steppe with high gypsum content while proper assessment should apply the scale for sulphate salinity with elevated gypsum content (Tab. 2).

Comparison of data from Table 2 shows that according to the currently practiced assessment it is possible to improve reclamation conditions of weakly-saline and soils of moderate salinity by feeding irrigation or planned soil leaching in the area of 583.08 ha (35.23\%) with the use of agro-reclamation measures in this area, 
Table 2. Gradient of soil salinity in the area of former collective N.B. Zardabi farm, Udjar District

\begin{tabular}{|c|c|c|c|c|c|c|}
\hline \multirow{3}{*}{ Salinity gradation } & \multicolumn{3}{|c|}{ Current classification in use } & \multicolumn{3}{|c|}{ Alternative (proper) classification } \\
\hline & \multirow{2}{*}{$\begin{array}{c}\text { total dissolved } \\
\text { solids } \\
\% \\
\end{array}$} & \multicolumn{2}{|c|}{ area } & \multirow{2}{*}{$\begin{array}{c}\text { total dissolved } \\
\text { solids } \\
\%\end{array}$} & \multicolumn{2}{|c|}{ area } \\
\hline & & ha & $\%$ & & ha & $\%$ \\
\hline Saline-free & $<0.25$ & 86.03 & 5.20 & $<0.80$ & 1110.00 & 67.05 \\
\hline Weakly saline & $0.25-0.50$ & 497.05 & 30.03 & $0.80-1.20$ & 330.00 & 19.94 \\
\hline Moderately saline & $0.50-1.00$ & 764.57 & 46.19 & $1.20-1.50$ & 90.00 & 5.44 \\
\hline Heavily saline & $1.00-2.00$ & 295.06 & 17.82 & $1.50-2.00$ & 112.71 & 6.81 \\
\hline Very heavily saline & $>2.00$ & 12.66 & 0.76 & $>2.00$ & 12.66 & 0.76 \\
\hline Total & & 1655.37 & 100.00 & & 1655.37 & 100.00 \\
\hline
\end{tabular}

In the remaining grounds, capital soil leaching is required in the area of 1072 thousand ha $(64.77 \%)$. But in fact, this soil category needs to be leached in the area of 1440 ha $(86.99 \%)$ and only 215.37 ha (13.01\%) should be subject to the capital soil leaching.

Similar inaccuracy appears in the reclamation assessment of soils, and consequently in selection of appropriate measures in Kur-Araz lowland. In the lowland with the total area of 2181.3 thousand ha monitored soils, 2060 thousand ha had a low gypsum content and 121.3 thousand ha are characterized by a high gypsum content (Tab. 3).

Table 3. Division of the areas of saline soil in Kur-Araz lowland

\begin{tabular}{|c|c|c|c|c|c|c|}
\hline \multirow{3}{*}{$\begin{array}{c}\text { Salinity gradation } \\
\text { (total } \\
\text { dissolved solids) }\end{array}$} & \multicolumn{2}{|c|}{ Current option } & \multicolumn{4}{|c|}{ Amended (adjusted) option } \\
\hline & \multirow{2}{*}{$\begin{array}{c}\text { total } \\
\text { dissolved } \\
\text { solids, } \%\end{array}$} & \multirow{2}{*}{$\begin{array}{c}\text { area } \\
\text { ha }\end{array}$} & \multicolumn{2}{|c|}{$\begin{array}{c}\text { soils with low gypsum } \\
\text { content }\end{array}$} & \multicolumn{2}{|c|}{$\begin{array}{c}\text { soils with high gypsum } \\
\text { content }\end{array}$} \\
\hline & & & $\begin{array}{c}\text { total } \\
\text { dissolved } \\
\text { solids, } \%\end{array}$ & $\begin{array}{c}\text { area } \\
\text { ha }\end{array}$ & $\begin{array}{c}\text { total } \\
\text { dissolved } \\
\text { solids, } \%\end{array}$ & $\begin{array}{c}\text { area } \\
\text { ha }\end{array}$ \\
\hline Saline-free & $<0.25$ & 564.7 & $<0.25$ & 564.7 & $<0.80$ & 59.6 \\
\hline Weakly saline & $0.25-0.50$ & 406.3 & $0.25-0.50$ & 406.3 & $0.80-1.20$ & 41.8 \\
\hline Moderately saline & $0.50-1.00$ & 391.7 & $0.50-1.00$ & 292.3 & $1.20-1.50$ & 2.9 \\
\hline Heavily saline & $1.00-2.00$ & 487.3 & $1.00-2.00$ & 477.6 & $1.50-2.00$ & 4.9 \\
\hline Very heavily saline & $>2.00$ & 331.3 & $>2.00$ & 319.1 & $>2.00$ & 12.1 \\
\hline Total & & 2181.3 & & 2060.0 & & 121.3 \\
\hline
\end{tabular}

Application of the Volobuyev's classifications with regard to the gypsum content shows that there are additional 121.3 thousand ha of soils with high gypsum content out of which 59.6 thousand ha are saline-free and 41.8 thousand ha are weakly saline. These soils can be successfully used under crops after application of the agro-reclamation measures. 
Consequently, consideration of the single factor shows that in Kur-Araz lowland the area suitable for agricultural purposes is not 971.0 thousand ha but 1072.4 thousand ha out of the total 2181.3 thousand ha.

Described facts indicate that the problem of reclamation assessment of soils for agriculture purposes and development of adequate measures for reclaiming their potential fertility is an important issue for the national economy, food security and environmental protection.

Presented data show the need of individual scientific approach in assessing soil conditions and defining the reclamation measures with the consideration of all influential factors. In spite of the numerous studies devoted to the problem of soil reclamation held by many scientific teams in the XX century, there are still a lot of unsolved issues which need to be investigated. Therefore, it is important to note the key issues, which should be solved in the field of land reclamation of saline soils.

\section{REFERENCES}

1. Cadastre of ameliorative condition of the irrigated lands in Azerbaijan republic for 01 January 2008, 2008. Baku, Hydrogeology-Ameliorative Service of Amelioration and water Economy OTJSC: 199.

2. Funds of the Azerbaijan Amelioration and Water Usage OJSC.

3. The problems of soil salinity and water sources, 1960. Moscow: 199.

4. The Works of the X International Congress of the Soil Scientists, 1974. Moscow: 19-27.

5. VolobuyeV V.P., 1976. The criteria of the soil salinity for designing the soil leaching. The thesis of the presentation in the third inter-agency conference on forecasting hydro-geological, engineeringgeology and soil-ameliorative conditions. Iss. 3. Moscow: 75-80.

\section{STRESZCZENIE}

\section{Ocena warunków odwodnień na terenach nawadnianych w Republice Azerbejdżanu}

Słowa kluczowe: nawodnienia, odwodnienia, zasolenie

Praca zawiera omówienie specyficznych warunków prowadzenia nawodnień i odwodnień gleb iłowych na terenie Republiki Azerbejdżanu. Przedstawiona została zmodyfikowana klasyfikacja zasolenia gleb, która z większą precyzją pozwala na ocenę możliwości i potrzebę prowadzenia prac odwodnieniowych.

Reviewers:

Prof. Edmund Kaca

Prof. Zygmunt Miatkowski 